\title{
Forage mass and structure of piatã grass deferred at different heights and variable periods
}

\author{
Hélio Henrique Vilela ${ }^{1}$, Braulio Maia de Lana Sousa ${ }^{1}$, Manoel Eduardo Rozalino Santos ${ }^{2}$, \\ Andreza Luzia Santos ${ }^{1}$, Camila Zimmer de Assis ${ }^{1}$, Gabriel de Oliveira Rocha ${ }^{1}$, Bruno \\ Damaceno Faria ${ }^{1}$, Domicio do Nascimento Júnior ${ }^{1}$
}

\footnotetext{
1 Universidade Federal de Viçosa, Departamento de Zootecnia, Viçosa/MG, Brasil.

2 Universidade Federal de Uberlândia, Faculdade de Medicina Veterinária e Zootecnia, Uberlândia/MG, Brasil.
}

\begin{abstract}
The objective of this study was to determine the deferment period and the most adequate initial sward height of Brachiaria brizantha cv. Piatã for deferment in the region of Viçosa, Minas Gerais. For so, the following characteristics were evaluated: masses and bulk density of forage and its morphological components, light interception by the sward, leaf area index, leaf angle, sward and extended tiller height and falling index of the deferred piatã grass. The three deferment periods assessed (65, 85 and 105 days) were randomized to the plots and the three sward heights (20, 30 and $40 \mathrm{~cm}$ ), randomized in the subplots. The experimental design was of completely randomized blocks, with three replicates, in a subdivided plots arrangement. Masses of forage, green stem and dead tissue were higher in the piatã grass managed with deferment period of 105 days. The mass of green leaf blade was higher in the piatã grass deferred with $20 \mathrm{~cm}$ height associated to the deferment period of 85 days, which had, as consequence, greater bulk density of green leaf blade. The interception of light by the sward was greater in the piatã grass kept longer in deferment associated with the higher leaf area index, regardless of its initial height. The heights of the sward and extended tillers were greater in the piatã grass under periods of 85 and 105 days of deferment; however, the falling index was not affected by the factors studied. In the region of Viçosa, Minas Gerais, B. brizantha cv. Piatã fertilized with $75 \mathrm{~kg} / \mathrm{ha}$ nitrogen and deferred with initial height of $20 \mathrm{~cm}$ and for a period of 85 days, from mid April, has adequate productivity and structure for animal production.
\end{abstract}

Key Words: Brachiaria brizantha, forage bulk density, leaf area index, light interception, pasture management

\section{Introduction}

In most of Brazil, especially due to reduction in the temperature and water availability, there is decrease or interruption of forage plant growth during the months of winter, which results in forage shortage in the production system. In this context, the pasture deferment, a management strategy of relatively lower cost when compared with ensiling or haymaking, consists of selecting pasture areas and exclude them from animal grazing, usually in the end of the summer or in the fall, in order to guarantee forage supply during its scarcity period.

Success in the use of deferred pastures depends mainly on the structure of the deferred pastures, which can be modified by the deferment period by the pasture height at the beginning of deferment. The duration of the deferment period affects the structural characteristics, forage production and the nutritional value of the pasture (Santos et al., 2009a), which will influence animal productivity. Therefore, the duration of this period must be based on the knowledge of the regrowth dynamics and, consequently, the proportion of the morphological components left.

The initial height of the pasture in the beginning of deferment influences its leaf area, which has a direct connection to the plant capacity of intercepting light radiation, which is one of the basic premises for maintenance of photosynthesis at its maximum level (Parsons et al., 1983). This way, the initial deferment height affects pasture growth rate, which, in turn, modifies the morphological and structure differentiation of the pasture.

In this sense, it is important to know the effects of initial height and deferment period on pasture production and structure. This knowledge enables identification and proposing rational management strategies, which result in deferred pastures with structure favorable to forage intake. However, there are few studies conducted with the objective of identifying the appropriate management measures for deferred pastures (Santos et al., 2009a,b), especially for Brachiaria brizantha cv. Piatã (piatã grass). 
Thus, this study was developed to establish adequate criteria for the proper utilization of piatã grass under deferred grazing in the region of Viçosa, Minas Gerais, by means of evaluation of production and structure of the sward managed with different initial heights and deferment periods.

\section{Material and Methods}

The experiment was conducted in the period from March 20 to July 2, 2010, in the Forage Sector of the Department of Animal Science at Universidade Federal de Viçosa, located in Viçosa, Minas Gerais, Brazil. Approximate geographic coordinates of the experiment location are $20^{\circ} 45^{\prime}$ south latitude and $42^{\circ} 51^{\prime}$ west longitude, and the altitude is $651 \mathrm{~m}$.

The climate of the region of Viçosa, according to the Köppen classification, is of the Cwa type, with annual rainfall at around $1,340 \mathrm{~mm}$, mean relative air humidity of $80 \%$ and mean maximum and minimum temperatures of 22.1 and $15^{\circ} \mathrm{C}$. The climatic data recorded during the experimental period were obtained at the meteorological station of the Department of Agricultural Engineering of UFV, located at about $500 \mathrm{~m}$ from the experimental area (Table 1).

An area of approximately $155 \mathrm{~m}^{2}$ with Brachiaria brinzantha cv. Piatã (piatã grass) established in December 2008 on a red-yellow Argisol open-clayey soil (Embrapa, 1999) was utilized. Soil samples were collected with the aid of Dutch auger $(0-20 \mathrm{~cm})$ and the results of the chemical analysis were: $\mathrm{pH}$ in $\mathrm{H}_{2} \mathrm{O}-5.2 ; \mathrm{P}-1.2 \mathrm{mg} / \mathrm{dm}^{3}$ (Melich 1) and $\mathrm{K}-22.0 \mathrm{mg} / \mathrm{dm}^{3} ; \mathrm{Ca}^{2+}-2.5 ; \mathrm{Mg}^{2+}-0.5$ and $\mathrm{Al}^{3+}$ $0.1 \mathrm{cmolc} / \mathrm{dm}^{3}(\mathrm{KCl} 1 \mathrm{~mol} / \mathrm{L})$. The area utilized went through correction procedures in previous experiments; a small presence of exchangeable aluminum was detected and the $\mathrm{pH}$ values were within the range considered satisfactory for the grass studied (CFSEMG, 1999), so liming was not performed. A dose of $50 \mathrm{~kg} / \mathrm{ha}$ phosphorus was applied as single superphosphate, $60 \mathrm{~kg} / \mathrm{ha}$ potassium, as potassium chloride and $75 \mathrm{~kg} / \mathrm{ha}$ nitrogen, as ammonium sulfate, at a single dose. Fertilization was performed at the beginning of each deferment period, in the afternoon, and, after fertilization, the plots were irrigated, aiming to elevate soil humidity and reduce the possible nitrogen losses by volatilization.

Deferment periods, randomized to the plots and initial sward heights, randomized to the subplots, were evaluated. Deferment periods were 65, 85 and 105 days. The initial sward heights for deferment were 20, 30 and $40 \mathrm{~cm}$. The design of randomized blocks was adopted, in an arrangement of subdivided plots, with three replicates. The criterion utilized for the defining of the blocks was the relief variation in the experimental area. Each block was subdivided, with the aid of wooden stakes, in three plots, to which deferment periods were randomly drawn. Each plot, in turn, was subdivided in three subplots with floor area of $5.76 \mathrm{~m}^{2}$, to which initial deferment heights were randomly drawn.

In the rainy season prior to deferment, the area was kept on grazing until the beginning of February. Then the area was excluded from animal grazing, and plants remained at free growth until the dates of the beginning of deferment, which happened on March 20, April 10 and May 1st, 2010. On these days, the piatã grass was lowered, by means of mechanic cut, to an average height of $55 \mathrm{~cm}$, for heights 20 , 30 and $40 \mathrm{~cm}$, which were the times when fertilization was also performed. All the area remained deferred until July 2, 2010, the appropriate date for the onset of the utilization of deferred pastures in the region of Viçosa (Santos et al., 2009b). On this date, all the response variables were also evaluated.

Light interception was measured with the sward analyzer LI-COR ${ }^{\circledR}$ model LAI 2000 at two points (seasons) per experimental unit. In each point, one reading was taken above the sward, and five on soil surface (below the sward), totaling two readings above the sward and ten below the sward. Data on leaf area index and the mean leaf inclination angle were obtained, utilizing the same device for the determination of light interception.

Sward and extended tiller heights were measured at 10 points per plot. Sward height, at each point, was determined with the aid of a graduated measuring stick and had the distance between the highest part of the plant in the sward and the soil as criterion. Extended tiller height was

Table 1 - Mean, maximum and minimum monthly temperatures, total monthly rainfall and total monthly evaporation from March 2010 to July 2010

\begin{tabular}{|c|c|c|c|c|c|c|c|c|}
\hline Month & Mean & temperature $\left({ }^{\circ} \mathrm{C}\right)$ & Maximum & temperature $\left({ }^{\circ} \mathrm{C}\right)$ & Minimum & temperature $\left({ }^{\circ} \mathrm{C}\right)$ & Rainfall (mm) & Evaporation (mm) \\
\hline March & & 22.9 & & 29.2 & & 19.1 & 184.8 & 121.7 \\
\hline April & & 20.4 & & 27.1 & & 16.3 & 28.1 & 103.4 \\
\hline May & & 18.4 & & 24.9 & & 14.3 & 35.4 & 76.0 \\
\hline June & & 15.3 & & 23.5 & & 9.9 & 0.9 & 73.6 \\
\hline July & & 17.3 & & 25.0 & & 12.4 & 0.0 & 84.9 \\
\hline
\end{tabular}


measured by extending five tillers of the grass vertically and noting the longest distance from the soil to the tip of the highest leaves. The creation of the leaf falling index aimed to determine, less subjectively, the lodging degree verified in a few deferred pastures and was calculated by the quotient between extended tiller height and sward height (Santos et al., 2009c).

For the determination of forage mass and its morphological components, all tillers within a $0.16 \mathrm{~m}^{2}$ square in two representative points of the average sward condition in each subplot were cut, near the soil level. Samples were conditioned in plastic bag and weighed in the lab. From each sample, two subsamples were collected; one of them was weighed, conditioned in paper bag and placed in forcedventilation oven at $65^{\circ} \mathrm{C}$ for 72 hours. The other subsample was separated manually into green leaf blade, green stem and dead tissue. Inflorescence and green leaf sheath were incorporated to the green stem fraction. The part of the leaf blade which did not present signs of senescence (green organ) was incorporated to the green leaf fraction. The senescent and dead parts of the stem and leaf blade were incorporated to the dead tissue fraction. After separation, components were weighed and oven-dried $\left(65^{\circ} \mathrm{C}, 72\right.$ hours $)$.

The bulk density of the forage and its morphological components, expressed $\mathrm{kg} / \mathrm{cm}$.ha, were calculated by the division of forage mass and the mass of its morphological components by the sward height, respectively.

The analyses of the experimental data were done with the software SAEG (Sistema de Análises Estatísticas e Genéticas, version 8.1). For each trait, a variance analysis was conducted, and when the interaction between factors was not significant, comparison between the marginal means of the levels of the primary (deferment period) or secondary (initial sward height) factors was performed. When the interaction between the factors was significant, comparison was made with the levels of one factor isolate for each level of the other factor. Means of the factors were compared by the Tukey test at significance level up to 5\% probability for occurrence of type I error.

\section{Results and Discussion}

The interception of light by the deferred piatã grass presented interaction between deferment period and height ( $\mathrm{P}<0.05$; Table 2). Under a deferment period of 65 and 85 days, the piatã grass with initial height of $20 \mathrm{~cm}$ intercepted less light in relation to the initial height of 30 and $40 \mathrm{~cm}$. On the other hand, there was no effect of initial height on the interception of light by the piatã grass subjected to deferment period of 105 days (Table 2).
Table 2 - Light interception (\%) in piatã grass swards under different deferment periods and initial heights

\begin{tabular}{lccc}
\hline Initial sward height $(\mathrm{cm})$ & \multicolumn{3}{c}{ Deferment period (days) } \\
\cline { 2 - 4 } & 65 & 85 & 105 \\
\hline 20 & $86.2 \mathrm{bB}$ & $94.7 \mathrm{aB}$ & $97.2 \mathrm{aA}$ \\
30 & $94.4 \mathrm{bA}$ & $97.3 \mathrm{aA}$ & $98.3 \mathrm{aA}$ \\
40 & $93.9 \mathrm{bA}$ & $98.0 \mathrm{aA}$ & $97.9 \mathrm{aA}$ \\
\hline
\end{tabular}

Means followed by the same lowercase letters in the row and uppercase letter in the column do not differ $(\mathrm{P}>0.05)$ by Tukey's test.

The lower light interception by the piatã grass deferred for 65 days and the initial height of $20 \mathrm{~cm}$ is due to the lower leaf area indices (Tables 3 and 4), a result from the short plant regrowth period, as well as the low area index of the remaining leaves after the cut in the beginning of the deferment period.

Additionally, the piatã grass deferred with initial height of $20 \mathrm{~cm}$ presented greater leaf angle $\left(49.0^{\circ}\right)$ when compared with heights of $30 \mathrm{~cm}\left(44.9^{\circ}\right)$ and $40 \mathrm{~cm}\left(44.2^{\circ}\right)$ (Table 4). Thus, the piatã grass deferred with initial height of $20 \mathrm{~cm}$ presented leaves more vertically positioned (erect), which reduces the light interception, for the angle of leaf insertion regulates the penetration of solar radiation in the sward (Bernardes, 1987).

Initial sward height did not affect the light interception at the end of the deferment period, when the piatã grass was deferred for 105 days. This result is due to the greater period when the plant remained deferred (105 days), as well as the beginning of deferment in a time of the year (March), with weather conditions more favorable to the forage grass (Table 1), in relation to the other periods evaluated. This enabled the piatã grass deferred for 105 days to reach a higher leaf area index and elevated light interception, regardless of the initial sward height.

The light interception by the piatã grass deferred with initial height of $30 \mathrm{~cm}$ and deferment period of 65 days (94.4\%) and with initial height of $20 \mathrm{~cm}$ and deferment period of 85 days (94.7\%) was close to $95 \%$. This can indicate that, in such conditions, the piatã grass presented structure favorable to animal intake and performance. However, pastures were lowered at different times of the year and at different heights, which can result in different pasture structures after the deferment. Thus, although these pastures presented practically the same leaf area index after the deferment ( 3.76 for pastures deferred with $30 \mathrm{~cm}$ height and for 65 days and 3.88 for pastures deferred with $20 \mathrm{~cm}$ height and for 85 days), the height of the pastures could be different, promoting different forage intake values.

Leaf area index, plant height and extended tiller height were lower $(\mathrm{P}<0.05)$ under a deferment period of 65 days in 
Table 3 - Structural characteristics of the piatã grass under different deferment periods

\begin{tabular}{lccc}
\hline Characteristic & \multicolumn{3}{c}{ Deferment period (days) } \\
\cline { 2 - 4 } & 65 & 85 & 105 \\
\hline Forage mass (kg/ha DM) & $4,940 \mathrm{~b}$ & $6,563 \mathrm{~b}$ & $8,352 \mathrm{a}$ \\
Green leaf blade mass (kg/ha DM) & $1,704 \mathrm{c}$ & $3,250 \mathrm{a}$ & $2,468 \mathrm{~b}$ \\
Green stem mass (kg/ha DM) & $1,172 \mathrm{~b}$ & $1,867 \mathrm{~b}$ & $3,355 \mathrm{a}$ \\
Dead tissue mass (kg/ha DM) & $2,064 \mathrm{ab}$ & $1,446 \mathrm{~b}$ & $2,529 \mathrm{a}$ \\
Sward height (cm) & $36.1 \mathrm{~b}$ & $58.3 \mathrm{a}$ & $63.1 \mathrm{a}$ \\
Extended tiller height (cm) & $43.4 \mathrm{~b}$ & $71.7 \mathrm{a}$ & $73.4 \mathrm{a}$ \\
Leaf area index & $3.3 \mathrm{~b}$ & $4.5 \mathrm{a}$ & $4.9 \mathrm{a}$ \\
\hline
\end{tabular}

Means followed by the same letter in the row do not differ $(\mathrm{P}>0.05)$ by Tukey test.

comparison with deferment periods of 85 and 105 days (Table 3). The deferment period of 65 days resulted in plants with lower developmental stage and consequently, with lower leaf area index. Contrarily, the shorter plant growth time determined greater leaf area index to the piatã grass deferred for a period of 85 and 105 days. In such condition, the greater competition for light between tillers is common, which probably made plants prioritize the allocation of carbon to the elongation of internodes, aiming to place the new leaves at the least shaded parts of the sward (Lemaire, 2001). This way, the greater stem elongation explains greater sward and extended tiller heights in the piatã grass under deferment periods of 85 and 105 days (Table 3).

Plant falling is associated to structural changes of the sward, promoting greater losses of forage during grazing and negatively interfering with the ingestive behavior of the animal (Santos et al., 2009c). Although there were differences between the sward heights and the height of the extended tillers, the leaf falling index was not affected $(\mathrm{P}>0.05)$ by deferment periods, presenting mean value of 1.21. This indicates that the levels of the factors studied did not result in falling of piatã grass tillers and, according to the criterion proposed by Santos et al. (2009c), pastures can be classified as normal and without plant lodging. Additionally, the absence of animals grazing contributed to the lower sward falling indices, since the presence of animals on pasture aggravates the pasture lodging.

Concerning the masses of total forage and green stem, their values were higher $(\mathrm{P}<0.05)$ in the deferment period of 105 days in relation to periods of 65 and 85 days (Table 3 ). The longer deferment periods promote more time for plants to utilize the resources of the environment in their growth and development processes, which increases the tissue synthesis, and consequently, the forage mass. The longer deferment periods also result in greater competition for light within the sward, and as a response, there is elongation of the internodes of tillers (Lemaire, 2001), a crucial factor for the accrual of stem mass in piatã grass (Table 3). This can create a sward structure unfavorable to forage intake, for, according to Carvalho et al. (2005), the stem is a barrier to defoliation itself, reducing the ease of forage harvest by the grazing animal.

As for the green leaf blade masses, its values were superior $(\mathrm{P}<0.05)$ in the deferment period of 85 days and lower $(\mathrm{P}<0.05)$ in the periods of 105 and 65 days, especially in the latter (Table 3). In the deferment period of 65 days, possibly, weather conditions more restrictive to plant growth (Table 1), added to the short time available to its growth, explain the low mass of green leaf blade. In fact, the unfavorable weather to the plant, starting from May, might have stopped the synthesis of new leaves and stimulated the senescence of the already existing ones. This argument is consistent, once the mass of dead tissues was high $(\mathrm{P}<0.05)$ in the piatã grass deferred for a period of 65 days (Table 3 ).

On the other hand, the piatã grass under deferment period of 105 days also presented lower green leaf blade mass because of the high senescence rates, which are common in the final phases of the development of plants under long growth period. Similar result was also obtained by Santos et al. (2010), who verified increase in the mass of dead tissues on B. decumbens cv. Basilisk pastures under different deferment periods. In fact, a too long growth period compromises the forage net production, as a consequence of the intensification of both losses by senescence and respiratory losses of carbon (Parsons et al., 1983) and also explains the high mass of dead tissues in the deferment period of 105 days (Table 3).

In addition, the higher leaf area index observed in the piatã grass deferred for longer (Table 3) contributed to increase in the shading of the sward, triggering senescence and death of organs shaded by the plants (Lemaire, 2001), which increases the dead tissue mass. Therefore, it is possible that in conditions of longer deferment period, some younger and shorter tillers were shaded by older and longer ones. Thus, these new tillers may have senesced, contributing to increase in the dead tissue mass.

The variations in the green leaf blade masses resulted in leaf/stem ratios of $1.4,1.7$ and 0.7 for the piatã grass deferred for periods of 65, 85 and 105 days, respectively. This characteristic is important in deferred pasture conditions, because for the deferment, the utilization of short grasses such as slender stem and high leaf/stem ratios are recommended, for these traits provide better nutritional value to the deferred forage and sward structure adequate to animal intake (Fonseca \& Santos, 2009). In this context, the piatã grass deferred for 85 days probably presented better structure, because of its higher leaf/stem ratio. 
Other relevant structural characteristics were not affected $(\mathrm{P}>0.05$ ) by deferment periods, such as the forage and green stem bulk densities, which presented means of $130.9 \mathrm{~kg} / \mathrm{ha} . \mathrm{cm}$ DM and $39.2 \mathrm{~kg} / \mathrm{ha} . \mathrm{cm}$ DM, respectively. According to criterion proposed by Santos et al. (2009c), in relation to plant falling index, pastures can be classified as normal and without lodging, which made the forage and green stem not be affected by the deferment periods. Opposite results were found by Santos et al. (2009a), who observed increase in the bulk density of the forage and its components, as the deferment periods of pastures of B. decumbens Stapf. cv. Basilisk became longer. In the study of Santos et al. (2009a), the longer deferment period promoted greater plant lodging and, consequently, greater bulk density of the forage and its components. The leaf angle also was not affected $(\mathrm{P}<0.05)$ by deferment periods, with average of $46.0^{\circ}$.

As for the effects of initial deferment heights, in the piatã grass structure, it was verified that, overall, the heights of the sward and extended tillers were proportional to the initial deferment heights (Table 4). These results can be explained, considering that the higher initial heights caused the remaining apical meristems to be located at higher parts of the sward during the beginning of the deferment period. Moreover, plants with greater initial heights reach the critical leaf area index more quickly, and with this, stem elongation is stimulated (Carnevalli et al., 2006), which has a positive effect on the heights of the sward and extended tillers.

The lowering of the piatã grass from $55 \mathrm{~cm}$ to the respective initial sward heights (20,30 or $40 \mathrm{~cm}$ ) ensured greater leaf area index at the beginning of the experiments to plants with more elevated initial heights (1.67, 2.13 and 2.41 for the heights of 20, 30 and $40 \mathrm{~cm}$, respectively), once more severe cuts remove higher amount of forage. The greater leaf area index is an essential factor for the interception of the light utilized for the synthesis of assimilates during the initial regrowth phase. This ensures quicker development

Table 4 - Structural characteristics of the piatã grass under different initial deferment heights

\begin{tabular}{lccc}
\hline & \multicolumn{3}{c}{ Initial sward height (cm) } \\
\cline { 2 - 4 } Characteristic & 20 & 30 & 40 \\
\hline Green leaf blade mass (kg/ha DM) & $3,075 \mathrm{a}$ & $2,251 \mathrm{~b}$ & $2,097 \mathrm{~b}$ \\
Green stem mass (kg/ha DM) & $1,651 \mathrm{~b}$ & $2,127 \mathrm{ab}$ & $2,616 \mathrm{a}$ \\
Sward height (cm) & $42.4 \mathrm{~b}$ & $56.5 \mathrm{a}$ & $58.7 \mathrm{a}$ \\
Extended tiller height (cm) & $53.4 \mathrm{c}$ & $64.2 \mathrm{~b}$ & $71.0 \mathrm{a}$ \\
Leaf area index & $3.7 \mathrm{~b}$ & $4.5 \mathrm{a}$ & $4.5 \mathrm{a}$ \\
Leaf angle $\left(^{\circ}\right)$ & $49.0 \mathrm{a}$ & $44.9 \mathrm{~b}$ & $44.2 \mathrm{~b}$ \\
Forage bulk density (kg/ha.cm DM) & $165 \mathrm{a}$ & $110 \mathrm{~b}$ & $117 \mathrm{~b}$ \\
\hline
\end{tabular}

Means followed by the same letter in the row do not differ $(\mathrm{P}>0.05)$ by Tukey's test. of leaf blades, explaining greater leaf area index values of the leaves of the piatã grass deferred at 30 and $40 \mathrm{~cm}$ (Table 4). The leaf area is important, for it is related to light interception by the sward, although high leaf area index can be harmful to forage accumulation, once it causes shading on the lower part of the sward, inhibiting tillering (Langer, 1972).

Although there was no effect of initial sward height on dead forage mass, which was, on average, 2,191 kg/ha DM, this variable of 7.2 and $19.3 \%$ was superior in the piatã grass deferred with initial height of $30(2,158 \mathrm{~kg} / \mathrm{ha} \mathrm{DM})$ and $40 \mathrm{~cm}(2,403 \mathrm{~kg} / \mathrm{ha} \mathrm{DM})$, respectively, in relation to that deferred with initial height of $20 \mathrm{~cm}$ (2,013 kg/ha DM). This demonstrates there is decrease in the quality of the forage with elevation in the initial sward height.

In fact, the piatã grass deferred with greater initial heights (30 and $40 \mathrm{~cm}$ ) presented lower green leaf blade mass when compared with the height of $20 \mathrm{~cm}$. This might have been a consequence of the grater leaf area index of the piatã grass deferred with initial heights of 30 and $40 \mathrm{~cm}$ (Table 4), which resulted in the shading of leaves and tillers located at the bottom of the sward. In addition, the leaf area index, intercepting more than $95 \%$ of the incoming light brings increase in the stem elongation of tropical grasses (Carnevalli et al., 2006), which explains the greater green stem masses in the piatã grass deferred with heights of 30 and $40 \mathrm{~cm}$, in comparison with that deferred with initial height of $20 \mathrm{~cm}$ (Table 4).

Forage mass was not affect $(\mathrm{P}>0.05)$ by initial deferment height and presented average of 6,618 kg/ha DM. It was expected that the greater initial heights would result in greater forage mass, due to the beneficial effects of the greater leaf area at plant regrowth. However, this absence of effect may have been a result of the different contribution of masses of green leaf blade and green stem in the total forage mass. In this sense, the high green leaf blade mass in the piatã grass deferred at $20 \mathrm{~cm}$ and the greater green stem mass in the piatã grass deferred at 30 and $40 \mathrm{~cm}$ (Table 4) resulted in similar total forage mass values.

Falling index also was not affected $(\mathrm{P}>0.05)$ by sward height at the beginning of the deferment and presented mean value of 1.21 . This result allows us to infer that the heights evaluated did not result in lodging of the piatã grass, which constitutes desired characteristics in deferred pastures (Santos et al., 2009c).

It is worth stressing that the response pattern of the leaf angle was opposite to that verified for the leaf area index of piatã grass deferred under different initial heights. The leaf angle was higher $(\mathrm{P}<0.05)$ in the piatã grass deferred with initial height of $20 \mathrm{~cm}$, i.e., its leaves were more uprightly placed (erect) in comparison with initial 
heights of 30 and $40 \mathrm{~cm}$ (Table 4). It is likely that the higher initial deferment heights provided plants with longer and heavier leaf blades, which presented their apical part in a more flat position, characterizing a leaf curvature. In the Piatã grass deferred with initial height of $20 \mathrm{~cm}$, however, shorter and lighter leaf blades did not preset such curvature and therefore remained more erect, as a consequence of their greater leaf angles (Table 4).

Forage bulk density was lower $(\mathrm{P}<0.05)$ for the piatã grass deferred with initial height of 30 and $40 \mathrm{~cm}$, when compared with that of $20 \mathrm{~cm}$ initial height (Table 4). Although the forage mass was not affected $(\mathrm{P}>0.05)$ by initial height, sward structure increased in the piatã grass deferred with greater initial heights. As forage bulk density is a result of the division of forage mass by the sward height, the greater forage bulk density of the piatã grass deferred with initial height of $20 \mathrm{~cm}$ can be understood. However, the bulk density of the green stem was not affected $(\mathrm{P}>0.05)$ by initial deferment heights, showing mean value of $39.2 \mathrm{~kg} / \mathrm{ha} . \mathrm{cm}$ DM.

The bulk densities of the live leaf blade and dead tissue were affected by the interaction between deferment periods and initial heights $(\mathrm{P}<0.05)$. The piatã grass deferred with initial height of $20 \mathrm{~cm}$, associated to deferment periods of 65 and 85 days, presented $(\mathrm{P}<0.05)$ the greatest values of live leaf blade bulk density. However, under deferment period of 105 days, the initial heights did not affect $(\mathrm{P}>0.05)$ live leaf blade bulk density (Table 5).

The piatã grass deferred with initial height of $20 \mathrm{~cm}$ produced greater live leaf mass and, concomitantly, presented lower height after the deferment period (Table 4). Thus, it is natural that it has greater live leaf bulk density. Greater leaf blade density is desirable, once, according to Euclides et al. (1999), maximum intake occurs when the animals are on pastures with high density of reachable leaves. In fact, studies conducted by Stobbs (1973a,b) and Chacon \& Stobbs (1976) demonstrated the importance of distribution and density of leaves and stems over the vertical profile of the pasture as determinant factors of its nutritional value and the size of the bite of grazing cattle.

However, the absence of effects of initial heights on the bulk density of the live leaf blade of the piatã grass deferred for 105 days is due to the elevated height of these plants $(63.1 \mathrm{~cm})$ (Table 3).

There was also interaction $(\mathrm{P}<0.05)$ between initial height and deferment period on the bulk density of dead tissues (Table 5). This way, greater bulk density of dead tissues $(\mathrm{P}<0.05)$ was verified for the piatã grass deferred at $20 \mathrm{~cm}$ and under deferment period of 65 days; however, in the piatã grass deferred for 85 and 105 days, the initial
Table 5 - Live leaf blade (LLBBD) and dead tissue (DTBD) bulk densities in piatã grass under different deferment periods and initial heights

\begin{tabular}{|c|c|c|c|}
\hline \multirow[b]{2}{*}{ Initial sward height $(\mathrm{cm})$} & \multicolumn{3}{|c|}{ Deferment period (days) } \\
\hline & 65 & 85 & 105 \\
\hline & \multicolumn{3}{|c|}{ LLBBD (kg/ha.cm DM) } \\
\hline 20 & $84.7 \mathrm{aA}$ & $89.7 \mathrm{aA}$ & $48.8 \mathrm{bA}$ \\
\hline 30 & $30.1 \mathrm{aB}$ & 47.3aB & 37.9aA \\
\hline \multirow[t]{2}{*}{40} & $37.9 \mathrm{aB}$ & $36.2 \mathrm{aB}$ & $34.4 \mathrm{aA}$ \\
\hline & \multicolumn{3}{|c|}{ DTBD (kg/ha.cm DM) } \\
\hline 20 & $91.4 \mathrm{aA}$ & 23.9bA & 42.6bA \\
\hline 30 & $40.8 \mathrm{aB}$ & 30.9aA & $37.1 \mathrm{aA}$ \\
\hline 40 & $49.7 \mathrm{aB}$ & 19.3bA & 42.7abA \\
\hline
\end{tabular}

Means followed by the same lowercase letter in the row and uppercase letter in the column are not different $(\mathrm{P}>0.05)$ by Tukey's test.

deferment height did not affect this variable response (Table 5) The greater dead tissue mass and the lower sward height (Tables 3 and 4) verified in the piatã grass deferred with initial height of $20 \mathrm{~cm}$ and deferment period of 65 days explain the greater dead tissue bulk density (Table 5).

Based on the results presented in this study, it is possible to concurrently employ heights and deferment periods aiming to benefit from the interactive effects on the production and structure of piatã grass.

\section{Conclusions}

In the region of Viçosa, Minas Gerais, Brazil, Brachiaria brizantha cv. Piatã fertilized with $75 \mathrm{~kg} / \mathrm{ha}$ nitrogen and deferred with initial height of $20 \mathrm{~cm}$ for a period of 85 days, from mid-April, presents appropriate productivity and structure to animal production.

\section{References}

BERNARDES, M.S. Fotossíntese no dossel das plantas cultivadas. In: CASTRO, P.R.C.; FERREIRA, S.O.; YAMADA, T. (Eds.) Ecofisiologia da produção agrícola. Piracicaba: Associação Brasileira de Pesquisa de Potassa e do Fosfato, 1987. p.13-48.

CARNEVALLI, R.A.; DA SILVA, S.C.; BUENO, A.A.O. et al. Herbage production and grazing losses in Panicum maximum cv. Mombaça under four grazing managements. Tropical Grasslands, v.40, p.165-176, 2006.

CARVALHO, P.C.F.; GENRO, T.C.M.; GONÇALVES, E.N. et al Estrutura do pasto como conceito de manejo: reflexos sobre consumo e a produtividade. In: SIMPÓSIO SOBRE VOLUMOSOS NA PRODUÇÃO DE RUMINANTES, 2., 2005, Jaboticabal. Anais... Jaboticabal: FUNEP, 2005. p.107-124.

CHACON, E.; STOBBS, T.H. Influence of progressive defoliation of a grass sward on the eating behaviour of cattle. Australian Journal of Agricultural Research, v.27, p.709-727, 1976.

COMISSÃO DE FERTILIDADE DO SOLO DO ESTADO DE MINAS GERAIS. Recomendações para uso de corretivos e fertilizantes em Minas Gerais - $5^{\text {a }}$ aproximação. Viçosa, MG, 1999. 359p. 
EMPRESA BRASILEIRA DE PESQUISA AGROPECUÁRIA EMBRAPA. Sistema brasileiro de classificação de solos. Brasília: EMBRAPA, 1999. 412p.

EUCLIDES, V.P.B.; THIAGO, L.R.S.; MACEDO, M.C.M. Consumo voluntário de forragem de três cultivares de Panicum maximum sob pastejo. Revista Brasileira de Zootecnia, v.28, n.6, p.1177-1185, 1999.

FONSECA, D.M.; SANTOS, M.E.R. Diferimento de pastagens: estratégias e ações de manejo. In: SIMPÓSIO, 7., E CONGRESSO DE FORRAGICULTURA E PASTAGENS, 3., 2009, Lavras. Anais... Lavras: NEFOR, 2009. p.65-88.

LANGER, R.H.M. How grasses grow. London, 1972. p.60. (Studies in Biology, 34).

LEMAIRE, G. Ecophysiology of grasslands: dynamic aspects of forage plant populations in grazed swards. In: INTERNATIONAL GRASSLAND CONGRESS, 19., 2001, São Pedro. Proceedings... São Pedro: Fundação de Estudos Agrários Luiz de Queiroz, 2001. p.29-37.

PARSONS, A.J.; LEAFE, E.L.; COLLET, B. The physiology of grass production under grazing. II. Photosynthesis, crop growth and animal intake of continuously-grazed swards. Journal of Applied Ecology, v.20, n.1, p.127-139, 1983.
SANTOS, M.E.R.; FONSECA, D.M.; BALBINO, E.M. et al. Capimbraquiária diferido e adubado com nitrogênio: produção e características da forragem. Revista Brasileira de Zootecnia, v.38, n.4, p.650-656, 2009a.

SANTOS, M.E.R.; FONSECA, D.M.; EUCLIDES, V.P.B. et al. Produção de bovinos em pastagem de capim-braquiária diferido. Revista Brasileira de Zootecnia, v.38, n.4, p.635-642, $2009 \mathrm{~b}$.

SANTOS, M.E.R.; FONSECA, EUCLIDES, V.P.B. et al. Características estruturais e índice de tombamento de Brachiaria decumbens cv. Basilisk em pastagens diferidas. Revista Brasileira de Zootecnia, v.38, n.4, p.626-634. 2009c.

SANTOS, M.E.R.; FONSECA, D.M.; GOMES, V. M. et al. Estrutura do capim-braquiária durante o diferimento da pastagem. Acta Scientiarum. Animal Sciences, v.32, n.2, p.139-145, 2010.

STOBBS, T.H. The effect of plant structure on the intake of tropical pastures. 1. Variation in the bite size of grazing cattle. Australian Journal of Agricultural Research, v.24, p.809- 819, 1973a.

STOBBS, T.H. The effect of plant structure on the intake of tropical pastures. 2. Differences in sward structure, nutritive value, and bite size of animals grazing Setaria anceps and Chloris gayana at various stages of growth. Australian Journal of Agricultural Research, v.24, p.821-829, 1973 b. 